\title{
Breaking the Silence: Efuru by Flora Nwapa
}

\author{
By \\ Reem Abdelsalam Anwar Mohamed \\ Assistant Lecturer- Faculty of Al-Alsun- Minia University
}

\begin{abstract}
African literature has, with very rare exceptions, been understood as literature by African men. Images of women were only given from a male perspective. Women were viewed from a biological viewpoint in the narratives of African men. Male writers represented women in their writings in subservient gender roles. They were portrayed as passive women who had no voice and accepted their status of subjugation. They were seldom portrayed as strong, independent women worthy of self-respect. These reasons led Flora Nwapa (1931-1993), the mother of the African novel by women and Nigeria's first female novelist to be published in English, to write her first novel Efuru in 1966 to speak up for marginalized women and protest on their status of being excluded. Nwapa brought the stories of women to attention with her writings by rejecting and confronting gender stereotypes and social traditions set by her patriarchal Igbo society to oppress women.

This paper seeks to explore Flora Nwapa's attempt to break the barriers of silence and the strategies she deploys in her novel Efuruto give a true picture of the deplorable situation of Igbo women in Nigeria. As a forerunner to a generation of African women writers, Nwapa created a new way of writing to question some of the unquestioned traditions of her Igbo society which oppress Nigerian women. This paper sheds the light on Nwapa's new way of writing and the strategies she uses to construct her novel and criticize Nigerian traditions which suppress women.
\end{abstract}


Flora Nwapa (1931-1993), the mother of the African novel by women, is Nigeria's first female novelist to be published in English at a time when African writing was dominated by men. With her first novel Efuru published in 1966, Nwapa was the forerunner to a generation of African women writers who started speaking for themselves at a time when writing was the exclusive preserve of men. African women were often presented as a subaltern and marginalized group who had no voice and accepted their status of subjugation. Many western scholars saw African women as silent and invisible and thus should be represented by western women and men writers. African women disproved this presentation; and hence it has become the African women's task to give a true picture of African women's lives as it actually is.

Mary ModupeKolawole, in "Space for the Subaltern: Flora Nwapa's Represenation and Re-Presentation of Heroinism" explains, "African women are products of several agencies that negate their self enhancement, and often the social structures put in place are obstacles to their ability to speak out" (225). According to Irene D' Almeida: "Silence represents the historical muting of women under the formidable institution known as patriarchy, that form of social organization in which males assume power and create for females an inferior status" (1).

Flora Nwapa recognizes the need to break the silence. She rejects the notion that African women as a subaltern group cannot speak and creates strong and true-to-life women who resist oppression in her writings. Through her writing, Nwapa tried to give a true picture of the deplorable situation of Igbo women in Nigeria. With the publication of Efuru in 1966, Nwapa crossed the boundaries of silence and opened new frontiers for other women to express themselves through writing. Nwapa had to find means to question some of the unquestioned traditions of her Igbo society which marginalize 
women like circumcision, polygamy, and preferring male children. Nwapa created a new way of writing, in which women were the center of focus. Most of her characters were women and through her characters she explored every aspect of female experience and questioned her society's traditions.

This paper analyzes Efuru by Flora Nwapa from a third world feminist perspective. Third world feminism emerged in response to Western mainstream feminism. Western feminism has not paid attention to the differences related to class, race, feelings and settings of women. It believes that women everywhere face exactly the same oppression merely by virtue of their sex/ gender. Chandra Mohanty (1991) in her powerful article Under Western Eyes: Feminist Scholarship and Colonial Discourses, criticizes western feminism on the grounds that it is ethnocentric and its mischaracterization of third world women's oppression. Therefore, third world feminism became popular. "It aims at generating descriptively reliable feminist analyses by third world women themselves of third world women's diverse forms of oppression and different modes of resistance on the ground" (Herr 2). Consequently, its focus has been on the typicality of problems of women of the third world nations in their particular/national contexts.

Third world feminists also disapprove tendencies to construct a single category of the colonized and thus ignoring differences. Spivak raises the question of voice in her essay "Can the Subaltern Speak?" and explores possibilities for subaltern women to recover their long silenced voices by speaking out and reclaiming their identities and reinscribing their subordinate position in society. Third world feminists like Nwapa, carefully examine and analyze third world women's oppression and resistance by paying attention to third world's women multidimensional and complex oppression through careful examinations of their local conditions and historical specifity. Hence, Nwapa sheds light on the Igbo traditions that suppress women such as 
courtship, marriage, circumcision, procreation, motherhood, infertility, children, polygamy and divorce.

\section{Courtship and Marriage}

Through reading Efuru, it is obvious that Nwapa is not against marriage per se. In her novels, Nwapa tries to counter the image given by male writers in their writings; the so-called voicelessness of African women. In Nwapa's first novel, Efuru, which Nwapa names after the protagonist of her novel Efuru. Efuru is presented as a distinguished woman who has a voice and a unique character: "Efuru was her name. She was a remarkable woman. It was not only that she came from a distinguished family. She was distinguished herself" (Efuru 7). She is admired by the entire village for her talent and manners.

Efuru refuses to obey traditional customs and decides to marry the man she loves. She is a self-reliant and independent woman and the voice of change in the society. Nwapa portrays Efuru as a woman whose actions indicate a need for change within the community. However, she shows her respect to her older customs as Efuru chooses to marry the man she loves without seeking permission but helps her husband gather the money to pay the dowry to her father. Nwapa protests against using daughters to gain money in the name of bride price or dowry: "Now a man who has four grown up daughters counts himself a very wealthy man. Each daughter will bring to the father at least a hundred pounds in cash, in raw cash" (Efuru 191).

Nwapa also disapproves limiting women's roles as wives and mothers. She gives a picture of women and their diverse roles and contributions to their society. Efuru is successful in trading and helps the people in her community who come to her for loans and is also a good wife for her husband:

Gilbert loved and respected her (Efuru). Efuru on the other hand knew the duties of a wife. She did not for one moment slack in her duties. 
She did not only take good care of her husband, she was swet to her mother-in-law.... So Gilbert's mother considered herself lucky to have Efuru as her daughter-in-law. She confined in her and treated her as her own daughter.... But what pleased gilbert's mother most was the fact that since her son had married Efuru things had moved well for him. Any trade she put her hand to was profitable. Soon Gilbert began to contemplate building a house of his own and buying a canoe.

Nwapa also disapproves the belief that the focus of existence for women is marriage. Efuru gets married twice and she leaves both her husbands after her marriages fall apart. It is clear that Nwapa disproves the belief that without a husband a woman is nothing. Efuru chooses independence and freedom and lives a life of economic success. Nwapa seems to be creating new identities and new images for women than the prescribed ones created by men who made women think that marriage means children. She was showing everybody that a woman's sole ambition is not marriage and children to crown the marriage and that there are other ways for women to achieve their identities and that a woman is still complete if she is unmarried or barren. Efuru's mother-in-law speaks of Efuru's good traits when her son left her for another woman saying: "My life has been one long suffering. The bright part of it came when my son married Efuru. But Adizua hated me. He did not want me to be happy, and so denied me that happiness I found in his marriage with Efuru. My son left his wife and ran away with a worthless woman" (Efuru 157).

\section{Circumcision}

One of the traditions of the Igbo society that Nwapa discusses in her novel Efuru is the bath or circumcision or clitoridectomy. It is believed that a 
woman must undergo this operation before she gives birth if she wants to have a safe child. To confirm the importance of the bath, Efuru is told the story of the woman who had lost her baby boy because "she did not have her bath before she had that baby who died after the dreadful flood.... She was afraid. Foolish girl. She had a foolish mother, their folly cost them a son, a good son" (Efuru 14). Efuru accepts the tradition without arguing and Nwapa gives us a detailed description of the process: "Efuru screamed and screamed. It was painful. Her mother-in-law consoled her. It will soon be over, my daughter, don't cry.' Meanwhile, Efuru's husband was in his room. He felt all the pain. It looked as if he were the one being circumcised" (Efuru 14).

After finishing Efuru's bath, the woman practitioner gave instructions. "She prepared a black stuff and put it in a small calabash and left it outside the room where Efuru was lying. - Sprinkle this on the feet of all the visitors before they come into the room. It will be infected, if it is not done...If anything goes wrong, send for me," she added (Efuru 14). Efuru's circumcision counseled by her mother-in-law is a ritual undertaken by women before they have a baby. Efuru's mother-in-law stresses the importance of "taking a bath" or circumcision by saying that: "A young woman must have her bath before she has a baby" (Efuru 11).

As a rite of passage, Efuru's circumcision is a prelude to her public recognition as a fully encultured member of Igbo society. A period of pampering and feasting follows the circumcision with Ossai, Efuru's motherin-law seeing to it that she was very well looked after. In her article "Efuru and Idu: Rejecting Women's Subjugation", Ada Azodo explains, "The majority (of women) who succumb (to being circumcised) are sequestered at home or in a special house called a "fattening room." For durations of one month to six or twelve months, they are fed fat like animals for slaughter, as they are readied for life with their future husbands" (172) (brackets mine). 
Nwapa describes this in the novel saying: "She was to eat the best food and she was to do no work. She was simply to eat, and grow fat. And above all she was to look beautiful" (Efuru 15). The newly circumcised girls are called "feasting girls" and their mothers "rubbed some cam wood on her hands and feet to tell people that her daughter has been circumcised" (Efuru 15).

After this period of rest, the "feasting girls" visit the market where they put themselves on display for the whole village. In some instances, the women go back and forth from their homes to the market several times a day differently adorned to show their beauty. The feasting girls are showered with gifts. In his article "Desire, the Private, and the Public in Flora Nwapa's Efuru and One is Enough", Shivaji Sengupta explains, "Flora Nwapa describes the "bathed" Efuru's entrance into the public with one of the best descriptions in the novel"(557):

So on Nkwo day, Efuru dressed gorgeously. She plaited her lovely hair very well, tied velvet to her waist and used aka stones for her neck. Her body was bare showing her beautiful breasts. No dress was worn when a young woman went to the market after the period of feasting. Her body was exposed so that people saw how well her mother or her mother-in-law had cared for her. A woman who was not beautiful on that day would never be beautiful in her life (Efuru 18).

Efuru was very beautiful and was praised by a lot of people who gave her money and congratulated her mother-in-law for taking good care of Efuru. Later, when Adizua is going to work Efuru rubs camwood on his body so that his friends at work would know that his wife had had her bath. It is clear that Efuru does not resist circumcision but she has her say on when she would return to the market and stop feasting. Efuru decides to go to the market after one month of feasting even though her mother-in-law wanted her to continue feasting for two months because of what people would say, but Efuru refuses 
and tells her "Never mind what people would say.... One month of confinement is enough. We have not got much money, and I want to start trading. Again we have not paid the dowry yet. I shall go to the market on Nkwo day" (Efuru 17-18).

Much has been written on circumcision and its effect on women. Western women see this practice as brutal and inhumane. However, African women are not united against it as it is a cultural practice. Nwapa's criticism of circumcision in the novel is subtle and ironical. In her article "Painful Entanglements: The International Debate on Female Genital Excision in African and African-American Literature", Elizabeth Bekers explains:

In fact, in Efuru, the rationale of the rite's existence is never questioned- not by any of the characters nor by the narrator- not even when Efuru's "bath" fails to offer the post-natal protection it promises for mother and child. Efuru's infant child dies and Efuru is never granted another chance at experiencing "the joy of motherhood" (49$50)$.

Nwapa explains in her novel that circumcision according to Igbo tradition is undergone to prevent children from dying but Efuru's daughter dies despite the circumcision. It is clear that Nwapa is indirectly problematizing the cultural belief of circumcision upheld by the society showing little belief in it and its importance.

\section{Procreation, Infertility, Motherhood and Children}

Motherhood has been the principal framework of identity for women in African literature, be it from the perspective of male writers or female writers. Efuru is described as a strong and successful woman but she is not successful in escaping the clutches of tradition. Only a few years after Efuru's first marriage to Adizua, Efuru sees herself as a failure. She loses many nights 
of sleep worrying about her infertility. Childlessness and bareness are seen as a failure in her society.

A year has passed since Efuru and Adizua got married and Efuru was not pregnant. She was worried and tried to comfort herself saying: "I am still young, surely God cannot deny me the joy of motherhood" (Efuru 24). Efuru's mother-in-law loved her and defended her when she heard people say bad things about her. She told Efuru, "a child would come when God willed it" (Efuru 24). However, Efuru's society viewed childlessness as a social stigma and the woman who did not conceive was considered a man: "they did not see the reason why Adizua should not marry another woman since, according to them, two men do not live together. To them Efuru was a man since she could not reproduce" (Efuru 24).

After Efuru and Adizua fail to conceive a child, Efuru and her father visit a dibia and he tells them that Efuru is not barren but she has not got many children in her womb and that she will have a baby next year if she does what he asks her. Efuru obeys the dibia's instructions and becomes pregnant and conceives a baby girl, Ogonim. Efuru could not comprehend her "success":

Efuru lay there thinking of it all. 'Is this happening to me or someone I know. Is that baby mine or somebody else's? Is it really true that I have had a baby, that I am a woman after all. Perhaps I am dreaming. I shall soon wake up and discover that it is not real (Efuru 31, emphasis added).

Efuru had been psychologically damaged by her inability to conceive and her attempts to fulfill her traditions. In her article "The Quest for Spiritual/Sexual fulfillment in Flora Nwapa's Efuru and The Lake Goddess", Linda Strong-Leek argues that:

The villagers begin to refer to Efuru not as a barren woman, but as a man. She is a "man" simply because she does not have the ability to 
reproduce readily and rapidly. Woman as commodity and child bearer is presumed in this instance. Efuru's value and femininity lie in her ability to procreate (540-541)

After Efuru conceives, Efuru's and Adizua's marriage starts to fall apart. Adizua starts to come home late and then abandons Efuru. Moreover, Efuru's daughter, Ogonim, suddenly develops a fever and dies. Adizua does not even return for his daughter's funeral and Efuru waits for him for a year but he does not return so she decides to go to her father's house indicating the end of her marriage to Adizua.

Efuru then marries Gilbert and motherhood also becomes a major concern in Efuru's second marriage. Two years pass and Efuru fails to conceive a child and backbiters start to talk about her. These voices represent the voice of the community:

The important thing is that nothing has happened since the happy marriage. We are not going to eat happy marriage. Marriage must be fruitful. Of what use is it if it is not fruitful? Of what use is it if your husband licks your body, worships you and buys everything in the market for you and you are not productive? (Efuru 137)

Some women see that a woman's only function in life is to procreate. Inher article "Efuru and Idu: Rejecting Women's Subjugation", Ada Azodo discusses that: "The society, as well as the woman, conclude form the beginning, without any scientific proof, that the infertility has to be the woman's fault (180). Efuru does not conceive and her husband remarries and she continues living with him but leaves him only when he accuses her of adultery.

Efuru keeps dreaming of Uhamiri, the Lake Goddess, and understands that she was chosen to be one of her worshippers. Efuru starts to achieve psychological balance and see her situation clearly while worshipping 
Uhamiri. She understands that Uhamiri cannot give her children because she has no children herself. Uhamiri is beautiful and rich but she does not have children so Efuru accepts her fate happily and Nwapa ends her novel explaining that Efuru slept "soundly" that night:

She dreamt of the woman of the lake, her beauty, her long hair and her riches. She had lived for ages at the bottom of the lake. She was old as the lake itself. She was happy, she was wealthy. She was beautiful. She gave women beauty and wealth but she had no child. She had never experienced the joy of motherhood. Why then did the women worship her? (Efuru 221)

Another important aspect which Nwapa examines in her novel Efuru is gender preference. A male-child is considered more important than a female-child. In Efuru, Nwapa attacks this system that elevates boys above girls. We see this incidence in the novel when a group of young girls who after enjoying Nwabata's story thanked him saying: "Thank you very much. Your wife will give birth to a baby boy" (Efuru 103). This statement reveals that a boy is perceived as a better gift than a girl and even though these girls are supposed to promote their gender, they wish that the man will have a baby boy because they understand that in their culture boys are of more value than girls.

Preference is also given to boy's education when the resources are not enough and girls are denied education. In Efuru, Nwapa gives a clear picture of this discrimination in the conversation between Eneberi and his friend Sunday. Sunday sends his sister to school and has this conversation with Eneberi:

'It is a good thing that you are sending her to school. But it is a waste of time sending them to school you know'... boys should be given the preference if it comes to that. If you had a little brother for instance 
and there is just enough money for the training of one, you wouldn't train Nkoyeni and leave the boy.' Sunday replies: 'You are right.' 'Sometimes these girls disappoint one, you know?... 'They get married before the end of their training and the money is wasted... in the kitchen.' (Efuru 191-192)

Men see that the most important role women play in the family besides bearing children is the upbringing of these children. This role is sometimes seen as limiting and confining women. Nwapa refers to the proper upbringing of children in her novel Efuru. Special care is given by women to girls who are expected to become wives and mothers. Efuru's mother-in-law expresses disappointment with Efuru's maidservant saying:

It is that silly girl, Ogea. She washed my wrappers and all of them will have to be washed again because there is still black soap on all of them. How is it that a grown-up girl like that is not able to wash clothes properly? How can she live in a man's house? (Efuru 181).

In her article "Myth, History, Culture, and Igbo Womanhood in Flora Nwapa's Novels", Theodora Ezeigbo comments that:

The concern shown by mothers as well as other elders in the community underscores how seriously they take the socialization of young people to proper behavior. There is a proper code of behavior expected to guide children's conduct which will usher them into responsible adulthood. These concerns are always expressed by women and they enforce the code. Women are, therefore, the custodians of tradition (62).

Women also use folktales to teach children how to behave properly and have good manners. Efuru gathers children and tells them stories with moral lessons. She tells them about "the woman whose daughter disobeyed her and as a result was married to a sprit" (Efuru 106). 
Another important aspect which Nwapa observes in her novel is motherhood and procreation because children are greatly valued, especially males, and a woman's worth is determined by how many male children she has. Igbos believe that the most important reason for marriage is procreation. Even if a marriage is based on love, having children is always the ultimate goal. If motherhood is so important, why then does Nwapa deprive her heroines from being mothers and bearing children? What is the logic behind that?

Theodora Ezeigbo explains: "Nwapa appears be to saying that there are other factors necessary for happiness. Companionship and love in marriage are as important as motherhood (if not more)" (65). Children alone do not give happiness or self-fulfillment to women. Efuru gives birth to a child after waiting for many years, but does she and her husband live happily together after that? Efuru's husband leaves her and her daughter dies. Efuru questions her purpose in life after her daughter dies saying: "Ogonim has killed me. My only child has killed me. Why should I live? . . Oh, my chi, why have you dealt with me in this way?"(Efuru 73).Efuru's words "why should I live" indicate the importance of motherhood to her and that without it, death is a possibility. Nwapa also gives the opposite picture of Efuru, NwabataNwosu, the woman who has so many children and she gives one of them away to Efuru to be her maid because she could not take care of them. Nwapa is also against parents who have more children than they can take care of.

Eventually, Efuru understands that she is not a failure because she is childless. She is strong, respected by her society and has great wealth and beauty. Efuru accepts her fate and fulfills her dream of being a mother by being a mother to the children in her village. Efuru gathers children and tells them stories that educate them. Nwapa seems to be questioning Igbo customs 
and traditions and offering other ways for women to be happy other than motherhood.

\section{$\underline{\text { Polygamy and Divorce }}$}

According to Roy Seiber and Roslyn Adele Walker in African Art in the Cycle of Life:

One of the most pervasive concerns of African societies is continuity. The future of the family and the group depends on the ability of the present generation to sire and bear children. Additionally, an individual's sense of social and biological completeness lies in his or her ability to become a parent, for one must depend upon one's children for the proper respect and consideration that is due age. Children not only guarantee the well-being of the individual in life, they will also provide a proper burial and ensure the transition of the spirit of the parent to the after world to take its place as an ancestor and possibly to reincarnate as a member of the family. Thus it is not surprising to find in African thought and art ubiquitous emphasis on human fertility (qtd in Nwankwo 348).

Therefore, Igbo women and men aspire to get married to bear children. According to Igbo customs, polygamy is accepted for continuity but the current wife should be consulted first. In Efuru, Adizua does not tell Efuru that he is seeing another woman and resorts to secrecy leaving home for days and then not coming home at all. Efuru's mother-in-law asks Efuru to be patient but Efuru feels that there is a woman behind Adizua's absence:

'Adizua is not going to Ndoni alone'... 'I am quite sure a woman is in this. His every movement suggests this. Adizua must be in the influence of some woman. He is still pleasing to my eyes, but I am not pleasing to his own eyes any more, and I cannot explain it.... How long will this last? How long will I continue to tolerate him? There is 
a limit to human endurance. I am a human being. I am not a piece of wood. ... God in heaven knows that since I married Adizua I have been faithful to him. Our ancestors know that since I ran away from my father's house to Adizua's that nobody, no man has seen my nakedness. But Adizua has treated me shabbily. He has treated me the way that only slaves are treated. God in heaven will judge us. (Efuru $53,58)$

Efuru's self-questioning leads to her final resolution. Efuru's daughter dies and Adizua does not come to the funeral. Messages are sent to him but he never returns. Efuru decides to go to her father's house after her daughter's funeral and divorce her husband. "By divorcing Adizua, Efuru rejects her mother-in-law's needless self-sacrifice and self-abnegation and her acceptance of abandonment and neglect, in firm and clear language"(Ezeigbo 67). Efuru says: "Perhaps self-imposed suffering appeals to her (Adizua's mother). It does not appeal to me. I know I am capable of suffering for greater things. But to suffer for a truant husband, an irresponsible husband like Adizua is to debase suffering. My own suffering will be noble" (Efuru 61$62)$.

Efuru's second marriage to Gilbert causes similar problems to those of her first marriage. Efuru marries Gilbert who again does not seem like a man who takes a second wife. Gilbert, who was educated in a Christian school and knows his Igbo traditions very well and pays Efuru's dowry, also does not consult his wife before he has children with another woman. When Efuru does not come pregnant four years into their marriage, Efuru mentions finding a second wife for him because she has not become pregnant but he refuses and appears uninterested. Gilbert disobeys traditions and does not ask Efuru before having a relationship with a woman and having a child and only admits the truth when he has no choice. 
Gilbert's son is two years old and he had not had enough courage for all that time to tell his wife. Gilbert's actions show that motherhood is revered by the Igbo community and that a man is allowed to do anything in order to have children. Later, Gilbert marries Sunday's sister, Nkoyeni and she and Efuru live together and people wonder why Gilbert chooses to marry Nkoyeni if he has a child by someone else.

Just as Efuru's first husband did not return for his daughter's funeral, Gilbert does not return for the funeral of Efuru's father. Messages are sent to Gilbert but he does not return for the burial. It is considered a sign of "disgrace" and Efuru thinks of killing herself (Efuru 204). He does not return to support his wife and he later explains that he was in jail for three months.

Gilbert's actions- not telling Efuru about his two-year-old son, not attending her father's funeral and not telling her why he was in jail- affect Efuru and she becomes ill for no apparent reason. Many dibias are consulted and they fail to give an explanation of what is happening. One of the dibias says that Efuru may have committed adultery and has to confess. Gilbert believes the dibias and asks Efuru to confess and that he will forgive her. Efuru is shocked that her husband believes that she had committed adultery.

Efuru proves herself innocent and leaves her husband for accusing her falsely of committing adultery. Efuru goes to her father's house for the second time rejecting her doctor friend Difu's advice to return to her husband saying: "If you are my friend, why then do you want me to go back to the man who accused me of adultery. You don't know the seriousness of the offense" (Efuru 220). Mary Mears argues that Efuru's doctor friend: "represents tradition and the male perspective, which is to forgive and remain with an adulterous husband who falsely accuses his wife in spite of the evidence" (Efuru 90). Efuru refuses to forgive Gilbert and devotes herself to worshipping Uhamiri and becomes more vibrant. 
From reading Efuru, it is clear that Flora Nwapa's heroine is created to show that the African woman as a subaltern has always tried to speak. In her novels, Nwapa presents protagonists who are controlled by the male establishment and challenge traditional roles to break through these barriers to find their voice. Nwapa also disapproves the belief that women are all womb with no feelings and that women's primary role is wifehood and motherhood. In Efuru, Nwapa ironically mimics popular reaction to a man marrying for the second time through Efuru's own words when she knew that her husband got married for the second time:

What is wrong in his marrying a second wife? It is only a bad woman who wants her husband all to herself. I don't object to his marrying a second wife, but I do object to being relegated to the background. I want to keep my position as the first wife, for it is my right... He is the lord and master, if he wants to marry her I cannot stop him (Efuru 53-55).

Efuru is saying what she knows men would expect to hear from her and what her father advises her on community expectations of a woman in almost the same words:

Did he (Adizua) bring a woman into the house?... God forbid. Your life is not ruined my daughter. Our ancestors will not agree. It does not matter my daughter if Adizua wants to marry another woman. It is only a bad woman who wants to have a man all to herself.... Meanwhile, go home and be a good mother to your daughter (Efuru $63)$.

To dismantle the societal structures which support the subjugation of women, women resort to divorce and single motherhood. Adeline Apena argues: "divorce became a remedy for emotional stress, shifting marital situations, self-liberation and survival. They (women) see no need to endure 
emotional depression especially as several options had become apparent" (286). She also adds that second generation women unlike their mothers are quicker to seek divorce as a way out of unpleasant marriages.

\section{Women the Custodians of Tradition}

There is no doubt that "African women", as Kolawole suggests, "are products of multiple subjugations, patriarchy, tradition, colonialism, neocolonialism, racism and gender imperialism all combine to act against the African woman's self-assertion" (Womanism 25). Tradition as a means of women's subjugation is the least one addressed in the critical works of many African critics because some scholars uphold the traditions of men with positivity.

Flora Nwapa protests the subjugation of women in patriarchal Nigeria. She explains that it involves a moral degradation of women which hinders them from making their full contribution to the society. In her book Male Daughters, Female Husbands: Gender and Sex in an African Society, Ifi Amadiume discusses that "women are taught early in life that they are a sensual class of human beings, created for the erotic pleasure of men" (36). Women are taught to value their bodies not their brains. Women are always put under surveillance by their families and the whole community. This is done under the guise of protecting them and as a part of their Igbo tradition. Ada Azodo argues:

Patriarchy, as an attitude towards women, is embedded in the social structure. Tradition favors men over women in all spheres of life. The uniqueness of individual women is not taken into account, nor is their personal worth assured. And so, early in life, males and females are classified and assigned gender roles. Men receive chauvinistic lessons on society's expectations of them in the public and in households, including being seen to be able to control their wives. Women, on the 
other hand, are tutored to be submissive to all males, including their husbands and brothers. They are to regard the primary foci of their lives as marriage and procreation, followed by the rearing of the offspring of those marriages(170).

The worst part is that women effect and perpetuate their own subservience and dehumanization believing that by doing this, they are following their Igbo traditions. Women see that it is their role to preserve these traditions and pass it on to younger generations of women without questioning because they believe that they are the custodians of these traditions.

Ajanupu, the chief custodian of traditional values in Efuru, commands Efuru's maid Ogea to "bend down and sweep like a woman"(Efuru 44-45). She also shouts at her while she is having her meal telling her "You don't sit like that when you are eating. Put your legs together. You are a woman" (Efuru 45). She also warns Efuru, her mistress, that: "She is a girl and will marry one day. If you don't bring her up well, nobody will marry her. By the way can she cook now?" (Efuru 125-126).

According to patriarchal ideals, good upbringing of women requires learning the arts of submission, cooking, and serving one's husbands and children. The wife must sit down by her husband while he eats, in order to pour his drinks. She may not eat with him. When the meal is over, she packs away his plates for washing while he dozes off to sleep. Early the following morning, she must wake up with the cock's crow to start the day's work, while her husband sleeps (Efuru 173). When she delivers her baby, she must do it alone or with a female friend. She must be especially careful, if it happens at home, and at night, not to disturb her lord and master (Efuru 32). Ada Azodo explains: "with such excellent machinery for ideological indoctrination 
carried out by elderly women, it is no wonder that, by puberty, young women are already conditioned for a life of submission (171).

By being the custodians of traditions, women are ignorant about the adverse consequences of perpetuating the same patriarchal rules that oppress them. Women's tradition-given role as custodians lead women to stand against each other to preserve traditions, effecting their own subservience and dehumanization, instead of cooperating to achieve solidarity to overcome patriarchy and stand out against the traditions which limit and shackle them and their freedom.

In Efuru, the whole society, including women, does not sympathize with barren women and find that a husband should replace his infertile wife even if the couple is happy without children. In Efuru's two marriages, women question Efuru's ability to conceive when she does not get pregnant early in her marriages and even blame her mother-in-law for not finding another woman for her son to marry. In the case of Efuru and her husband Gilbert, Efuru's mother-in-law is blamed for not finding a wife for her son and for waiting this long for Efuru to have children "Did Efuru give you medicine that you have lost your senses? You see your only son married to a woman who is barren, this is the fourth year of the marriage, and you sit down and hope?" (Efuru 175).

Throughout the novel, most women are envious and jealous from one another and even when pregnancy occurs early in marriage, which should be a sign for happiness for the couple; women are still no less hurtful to other women. When Nkoyeni, the second wife of Enebri, is pregnant early in her marriage the village gossip, Omirima, spreads the news of her pregnancy with indifference saying: "So what? Is she the only woman pregnant this season? It is expected that she should have a baby before the year is out. If no baby 
comes in the first year, it is our duty to probe her girlhood, and find out why" (Efuru 197)

Women see that their foci of existence are marriage and conceiving children. Even though barren women are psychologically damaged by their inability to conceive, they attempt to search for replacements for their husbands in order to enlist themselves in the good books of their husbands and to fulfill their traditions. The society, as well the woman, concludes from the beginning without any scientific proof, that the infertility has to be the woman's fault.

Moreover, women are the ones who show preference for boy children as opposed to girls: Omirima advices Enebiri's mother on the issue of her son's illegitimate son:

But don't you think you should persuade your son to marry the mother of his son? A woman who gave birth to such a boy should be married. You don't know tomorrow. Nkoyeni won't be barren of course- she is pregnant already. But nobody knows whether she is going to have a girl or boy. She might take the footsteps of her mother who had four girls and a boy" (Efuru 196).

When Efuru welcomes Eneberi's illegitimate son from another woman, Efuru is seen as a good woman and wife but when Nkoyeni, Eneberi's other wife who is educated, threatens to leave if Eneberi's boy does not return to his mother and leave the house, she is seen as a bad woman and is condemned for her actions and women ask her mother-in-law: "Why did you not let her go? There are so many girls in town who will gladly be your son's wife. This is nothing but weakness" (Efuru 197). They see that Nkoyeni's action is a result of her foreign education which they condemn. Nkoyeni is seen as troublesome because she dares to ask her husband questions and has a say in things. Nkoyeni falls out of favor with everyone in the household when she 
demands to know why their husband deserted them for three months, and whether there is truth in the rumors that he had been imprisoned for theft for three months in Onitcha (Efuru 214). Ada Azodo discusses that:

Nkoyeni's Western education is blamed for her stand on issues. So, society condemns altogether the new attitudes arising from the teachings of the foreign schools. The denial of education to women means that for a long time there will be a very small percentage of women who are in a position to contribute either rationally or skillfully to the growth of the nation. When there are scarce resources, boys rather than girls are sent to school to learn. Women's education is branded a waste of time, since they usually drop out of school to get married and raise a family. It does not matter that it is the men themselves who make conscious effort to pluck them away early before they develop enough self-esteem to challenge their oppressive ideas. (169)

Even though Efuru does not receive Western education and does not blame her husband for his actions, Eneberi believes what people say about Efuru committing adultery and asks her to tell him everything and that he will forgive her. On behalf of Efuru, who was sick and weak at that time, Ajanupu, one of the main custodians of tradition in the novel, fights back for Efuru. Gilbert gave Ajanupi a slap which made her fall down but Ajanupu "got up quickly for she was a strong woman, got hold of a mortar pestle and broke it on Gilbert's head. Blood filled Gilbert's eyes" (Efuru 217).

The pestle for grounding corn has always been of one of the symbols of African womanhood and, on occasion, a weapon of war. The novel ends with Efuru thanking Ajanupu for putting up a brave fight on her behalf. From this incident, we see an example of women helping each other and standing up for one another even if that requires breaking long-prevailing traditions 
and beliefs to acquire their self-worth. Efuru leaves her husband realizing that she alone can make and unmake her own happiness.

Throughout the novel, Nwapa writes and rewrites the changes of her society and reflects these changes on women in her fictional texts. Helen Chukwuma comments:

Nwapa's literary domain is women. In her novels and short stories,

Nwapa bared the soul of woman, she showed her as flesh and blood nursing her own dreams and aspirations, being hurt and giving hurt and breaking with tradition when it chokes her. This has never been done before. (115)

Nwapa's goal in her writing is that women should learn to eschew self-hatred and envy and that women could achieve social, economic and emotional independence when they assist one another. Nwapa is clearly stressing that the way for women to earn equal status and humane treatment in their societies is by challenging traditions and old habits that shackle them. She also highlights that women's focus should not be on the rivalry between women and men but on supporting one another to achieve social reform.

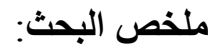

كسر حاجز الصمت فى رواية/يفورو لفورا نوابا 
يتناولهذا البحث موضــوع كسـر حاجز الصــتوذلك منخلالدر اســة رواية إيفورو (1966)

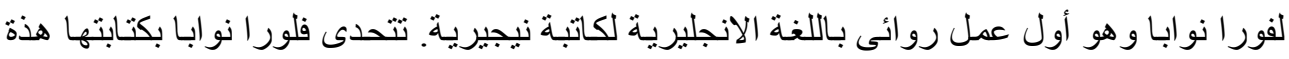

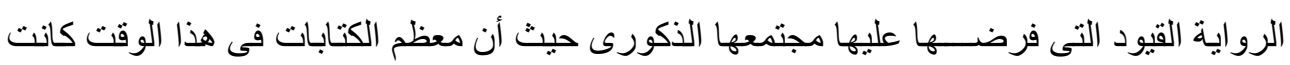

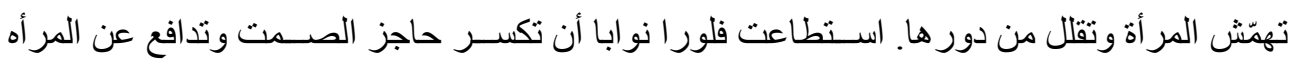

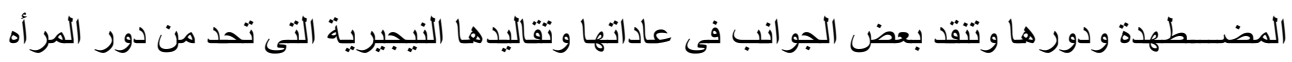

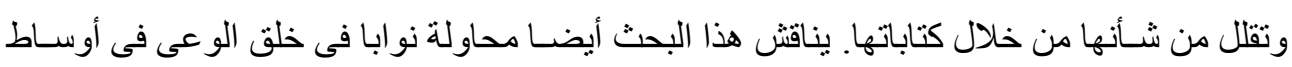

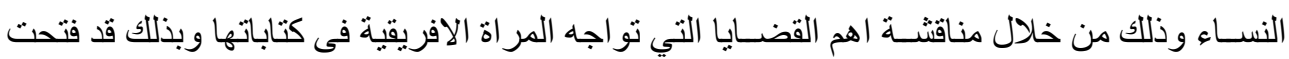
نو ابا الطريق أمام غير ها من النساء النيجيريات لكسر حاجز الصمت ومناقثة قضايا المر أه النيجيرية ومعاناتهن من وجهة نظر هن للبحث عن حلول لها. 


\section{Works Cited}

Amadiume, Ifi. Male Daughters, Female Husbands: Gender and Sex in an African Society. London: Zed Books, 1987. Print.

Apena, Adeline. "Beaing the Burden of Change: Colonial and Post-Colonial Experiences in Flora Nwapa's Women Are Different" Emerging Perspectives on Flora Nwapa: Critical and Theoretical Essays. Ed. Marie Umeh. Trenton, NJ: Africa World Press, 1998. Print. 277-289.

Azodo, Ada. "Efuruand $\underline{I d u}$ : Rejecting Women's Subjugation." Emerging Perspectives on Flora Nwapa: Critical and Theoretical Essays.Ed. Marie Umeh. Trenton, NJ: Africa World Press, 1998. Print. 161-187.

Bekers, Elizabeth. "Painful Entanglements: The International Debate on Female Genital Excision in African and African-American Literature."Africa and Its Significant Others: Forty Years of Intercultural Entanglement. Eds. Isabel Hoving, Frans-Willem Korsten, Ernst van Alphen. NY: Rodopi, 2003. 45-60.

Chukwuma, Helen. Ed. "Flora Nwapa is Different." Feminism in African Literature: Essays on Criticism. Enugu: New Generation Books, 1994. Print. 115-130.

D' Almeida, Irene. Francophone African Women Writers: Destroying the Emptiness of Silence. Gainsville, Florida: Florida UP, 1994. 
Ezeigbo, Theodora. "Myth, History, Culture, and Igbo Womanhood in Flora Nwapa's Novels."Emerging Perspectives on Flora Nwapa: Critical and Theoretical Essays.Ed. Marie Umeh. Trenton, NJ: Africa World Press, 1998. Print. 51-76.

Herr, Ranjoo. "Reclaiming Third World Feminism: or Why Transnational Feminism Needs Third World Feminism." Meridians: Feminism, Race, Transnationalism, vol. 12, no. 1, 2014, pp. 1-30.

Kolawole, Mary. "Space for the Subaltern: Flora Nwapa'sRepresenation and Re-Presentation of Heroinism." Emerging Perspectives on Flora Nwapa: Critical and Theoretical Essays.Ed. Marie Umeh. Trenton, NJ: Africa World Press, 1998. Print. 223-240.

---. Womanism and African Consciousness. Trenton, NJ: Africa World Press, 1997. Print.

Mears, Mary. Choice and Discovery: An Analysis of Women and Culture in Flora Nwapa's Fiction. PhD Dissertation, U of South Florida, 2009.

Mohanty, Chandra. "Under Western Eyes: Feminist Scholarship and Colonial Discourses." Boundary 2, Vol. 12, No. 3, (Spring - Autumn, 1984), pp. 333-358.

Nwankwo, Chimalum. "The Lake Goddess: The Roots of Nwapa's World." Emerging Perspectives on Flora Nwapa: Critical and Theoretical Essays.Ed. Marie Umeh. Trenton, NJ: Africa World Press, 1998. Print. 334-352.

Nwapa, Flora. Efuru. London: Heinemann, 1966. Print. 
Sengupta, Shivaji. "Desire, the Private, and the Public in Flora Nwapa'sEfuru and One is Enough." Emerging Perspectives on Flora Nwapa: Critical and Theoretical Essays.Ed. Marie Umeh. Trenton, NJ: Africa World Press, 1998. Print. 549-565.

Strong-Leek, Linda. "The Quest for Spiritual/Sexual fulfillment in Flora Nwapa's Efuru and The Lake Goddess."Emerging Perspectives on Flora Nwapa: Critical and Theoretical Essays.Ed. Marie Umeh. Trenton, NJ: Africa World Press, 1998. Print. 531-548. 